\title{
A STUDY ON STATE OF GEOSPATIAL COURSES IN INDIAN UNIVERSITIES
}

\author{
Sulochana Shekhar \\ Central University of Karnataka, Kalaburgi \\ sulogis@gmail.com
}

Commission VIII

KEY WORDS: Geoinformatics, University, Higher Education, Master degree, Doctoral Degree, Geospatial Industry

\begin{abstract}
:
Today the world is dominated by three technologies such as Nano technology, Bio technology and Geospatial technology. This increases the huge demand for experts in the respective field for disseminating the knowledge as well as for an innovative research. Therefore, the prime need is to train the existing fraternity to gain progressive knowledge in these technologies and impart the same to student community. The geospatial technology faces some peculiar problem than other two technologies because of its interdisciplinary, multi-disciplinary nature. It attracts students and mid career professionals from various disciplines including Physics, Computer science, Engineering, Geography, Geology, Agriculture, Forestry, Town Planning and so on. Hence there is always competition to crab and stabilize their position.

The students of Master's degree in Geospatial science are facing two types of problem. The first one is no unique identity in the academic field. Neither they are exempted for National eligibility Test for Lecturer ship nor given an opportunity to have the exam in geospatial science. The second one is differential treatment by the industrial world. The students are either given low grade jobs or poorly paid for their job. Thus, it is a serious issue about the future of this course in the Universities and its recognition in the academic and industrial world.

The universities should make this course towards more job oriented in consultation with the Industries and Industries should come forward to share their demands and requirements to the Universities, so that necessary changes in the curriculum can be made to meet the industrial requirements.
\end{abstract}

\section{INTRODUCTION}

\subsection{Geospatial technology}

Even though people started using SMART phones and google maps and GPS navigation in their cars, talking about Geospatial technology will certainly bring a blank look on their faces. It is because many of us are not aware of this technology in detail. Knowingly or unknowingly geospatial technology has an essential part of our daily life and has made us more and more dependent on this spatial technology.

The Geospatial technology popularly known as Geoinformatics is the amalgamation of three spatial technologies such as Remote sensing, Geographic Information Science (System) and the Global Positioning System. When these technologies are applied together to deal with any spatial problems, the results are amazing. It gives more practical and meaningful solutions to solve the spatial problems and assists in decision making by providing alternatives. Hence there is a huge demand for geospatial experts in different capacities in many Organisations that includes both the Government and Private sectors.

Amidst the student community, this technology brought lots of anticipation, hope and interest to pursue their higher education in this field. Thinking of Campus selection in high profile Industries and good salary packages, students are keen to study spatial technology and by seeing this demand, many Universities started introducing this courses at various levels such as M.Sc., M.Tech, B.E, PG Diploma, B.Sc.-Applied and, Certificate course etc.
At this juncture, there are few things that demands serious concern from all of us. First among that is the dissemination of the knowledge of spatial technology and to teach, our faculties should have been trained and must have a thorough knowledge of this spatial science. The nature of the subject also demands multi-disciplinary approach and a basic knowledge of Physics, Maths, cartography, Geography, Geology, computer science and Engineering. Planners, Architects, Surveyors and Military services are also contributing for application development in this field. Each one has a different role in the development of contents in the subject.

Based on this we can divide the subject content into Four sections. The first part is the basic concepts of the spatial science that includes the science behind remote sensing, the need for Geographic component in Geographic Information Science and the functioning of Global Positioning system. The second part is mainly concerned with sophisticated software, open source software, compatible hardware and customising the tools, Database management and other web (GIS) development. The third is the practical part i.e., application of theory into real world problems. Lots of application tools, methodologies to apply, tutorials and case studies on different fields such as Agriculture, Forestry, Urban, Rural, Disaster, Environment and many more are covered in this section. The last part covers the geospatial policy and legal regimes.

Thus, it shows that teaching of geospatial science is possible only with inter disciplinary /multi-disciplinary approach and needs expert teachers from various subjects or a teacher with versatile expertise. 


\subsection{Geospatial Courses}

Geospatial science is taught mostly at Post graduate level except in engineering courses, where it is being taught at undergraduate level as Bachelor of Engineering (BE)/ B.Tech in Geomatics/ Geoinformatics. It is also taught as one of the elective subject in BE Civil Engineering, B Planning courses at undergraduate level. $\mathrm{PhD}$ in Geoinformatics is also there in some selected Institutions that Includes IIRS (Andhra University, Pune University), IITs, Bharati Vidyapeeth, Pune and Symbiosis Institute of Geoinformatics, Pune. The Post graduate courses also varies from M.Sc., in Geoinformatics, M.Sc., Applied Geography and Geoinformatics, M.Tech., in Geoinformatics and M.Tech., in Remote sensing for two years, Post Graduate Diploma for one year. There are B.Sc. Applied Remote sensing course for one year and certificate courses varying from six months to two months also taught at University level.

\section{DEMAND FOR GEOSPATIAL WORKFORCE}

\subsection{Categories of Geo spatial professionals}

The Task Force on Geospatial Education (MHRD Report, 2013) in their report recognised the requirement of three categories of Geospatial professionals based on the depth of knowledge required, type of knowledge imparted and intended professional level of the students. The geospatial professionals are required at three levels are.

Level 1 - Geospatial skilled work-force

- a category of large number of human resources required to form the "pyramid-base" (Figure 1)and who will be the large work force for survey/mapping/GIS operators etc.

Level 2-Technical Geospatial Professionals

- are a large number of geospatial professionals who have specific training and knowledge for specific tasks - these form the "pyramid middle". These are graduates with a specific 9-12 months training in geospatial technology (GPS Surveying; Data Capture from Images; Geodatabase creation; QA/QC processes and so on).

Level 3- Geospatial experts

- who have a graduate/ masters degree in geospatial technology form the "pyramid top" of the workforce. These would be the project managers who are capable of handling geospatial projects independently.

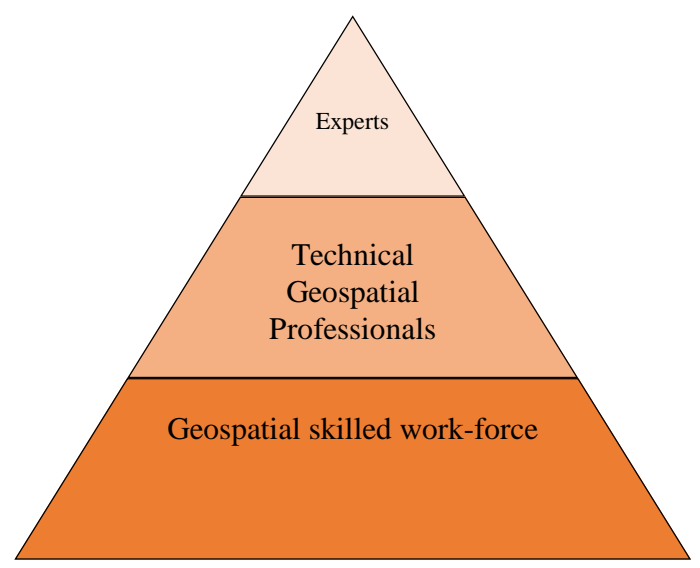

Figure 1 Geospatial Professional categories
The current scenario of the University system is capable of producing the lower part of the Pyramid in more numbers than the middle and top of the pyramid. Lack of subject experts, adequate infrastructure and other aspects impact the quality of education and knowledge generated and so restricts the capacities to the lower-end, labour-intensive activities - say, surveying and mapping. This is not a good scenario as it makes India a "labour-force" as against a "knowledge force" in geospatial technology (Volume 2, MHRD Report 2013).

\subsection{Demand in Government sector}

The Indian geospatial industry growth rate is significantly higher than worldwide geospatial industry growth and also has potential future growth. The significant factor contributing to the growth of geospatial industry is that the Government of India has budgeted a wide range of initiatives that have a significant geospatial component. For example "Geospatial Infrastructure Bill" passed by the Delhi State Assembly. The bill seeks to use geospatial technology for planning and executing various development projects and utility services (Geospatial world, 2011). The recent Government initiatives such as "Minimum Government and maximum Governance", building Smart Cities and Compulsory GIS mapping in Cities, Slum development programs are other good examples. These initiatives, along with state and local level initiatives, have the potential to motivate a much stronger internal capacity for geospatial technology in India.

The current plans and initiatives of Government of India call for geospatial capabilities that are larger than what the geospatial industry can provide at the once. The government and the geospatial industry will have to consider ways/means to improve the educational system for geospatial workers at skilled and semi-skilled levels.

A rough estimate states that over the next 3-4 years there will be a need of over 100000 professionals (Table 1, Source: MHRD Report, 2013) in this area at different levels. Various organizations needing Geospatial professionals include: Govt Organizations like IIRS, SAC, NRSC, ISRO, State Space Application Center, RRSSC, DRDO (DTRL), ADIRIN, SOI, NATMO; Software Industries like ESRI, AUTOCAD, AUTODESK, ERDAS, BENTLEY, GOOGLE, MICROSOFT; Private Organizations like RMSI, TATA Consultancy, EICHER; Govt Undertakings like ONGC, SHELL, IOCL; Administrative units like MUNICIPALITIES, Town \& Country Planning, Urban Authorities, Jal Nigam, PWD, Technical and Research Institutions (for teaching and R\&D work) etc.

\begin{tabular}{|l|l|l|}
\hline Geospatial work force & $\begin{array}{l}\text { Present } \\
\text { Availability }\end{array}$ & $\begin{array}{l}\text { Estimated } \\
\text { Additional } \\
\text { need }\end{array}$ \\
\hline $\begin{array}{l}\text { Skilled workforce for } \\
\text { Surveying and mapping }\end{array}$ & $\begin{array}{l}15,000- \\
20,000\end{array}$ & $\begin{array}{l}20,000 \\
(4000-5000 \\
\text { per year })\end{array}$ \\
\hline $\begin{array}{l}\text { Trained workforce for } \\
\text { Surveying and mapping, } \\
\text { Geodatabase and GIS } \\
\text { apps }\end{array}$ & $6000-10,000$ & $\begin{array}{l}15,000 \\
(2000-3000 \\
\text { per year })\end{array}$ \\
\hline $\begin{array}{l}\text { Educated professionals } \\
\text { for Survey/ mapping, } \\
\text { Geodatabase and GIS } \\
\text { apps }\end{array}$ & $800-1200$ & $\begin{array}{l}5000-8000 \\
(1000-1500 \\
\text { per } \\
\text { Year) }\end{array}$ \\
\hline Trained users & & $500,000(50-$ \\
\hline
\end{tabular}




\begin{tabular}{|l|l|l|}
\hline $\begin{array}{l}\text { development who } \\
\text { would be users }\end{array}$ & 50000 & $\begin{array}{l}\text { 100K per } \\
\text { Year })\end{array}$ \\
\hline
\end{tabular}

Table 1 Requirements for the Indian geospatial activity

\section{PRESENT SCENARIO AT UNIVERSITY LEVEL}

As we understood, there is a great demand for trained persons, skilled work force, Professionals both in Government and Private sector and, there is a need to supply the required workforce not only with the quantity but also with quality. Here comes the role of Universities. Unfortunately, they are suffering to achieve the required target both in terms of quantity as well as quality.

The wide use of this technology attracts the students and professionals who are in the beginning of their career to take up this course for their future career. Since the multi-disciplinary nature of the subject fascinates students and young professionals from different background, they always compete among themselves to stabilise their position.

\subsection{Students intake problem}

Only few Universities have Geospatial course at undergraduate level therefore there are not many feeding Institutions for Post graduate courses. Hence the Post graduate courses in Geospatial science have a wider options for admitting the students from other disciplines. Students from Physics, Maths, Chemistry, Computer Science, Geography, Geology, Environmental science and even from other life science background students, who would like to study the M.Sc. Geoinformatics at their post graduate level are given a chance. So irrespective of the students' background, they have to be treated at par to learn Geospatial Science.

\subsection{Problems in curriculum design and teaching}

DST Committee Report (Prithvish Nag Committee, 2010) insisted the need for a standardised curriculum design for diploma, bachelors and post-graduate courses in all universities; constant training of teachers to update their knowledge and urgent need for infrastructure improvement in the universities etc.

The curriculum in most of the Universities was designed by diluting the technical aspects of Geospatial Science and not updated as per the current developments in the field. It is mainly because of the lack of subject experts available for teaching. Secondly the technology is developing so fast that the knowledge imparted to the student becomes obsolete or at least obsolescent by the time he or she completes the course (Geospatial World, Sep 2014)

Teaching this courses need subject experts from various disciplines. Though the teachers who got trained on the basics of this technology can impart that knowledge to the students but they can do that only to a certain extent. Due to the Lack of further and advanced training, updated software and high end computer systems, they are finding difficult to cope up with new challenges of Geospatial teaching. Another issue is, most of the teachers are in the middle of their career and adopting this new techniques are very difficult without proper background and training. There are no specific training programs (tailored as per the need) to update their knowledge with respect to their prior background. Therefore neither a general basic program nor an advanced training program can solve this problem.

Actually we need two kinds of teaching faculties with the first kind of teachers teaching the technical aspects of the subject with maths and computer science background and second kind strengthening the spatial aspects for better application by using these techniques with Geography and other Earth sciences background. Indeed both kinds of teachers are complementary to each other and should work together to impart the Geospatial course subjects to the students. This holistic approach is the need of the hour.

\subsection{Placement problems}

Many universities have placement cells for students' benefits. After completing their Master degree, students look for placements in big industries with huge salary package. Unfortunately except a few, most of them were offered low grade work and are poorly paid. In particular students with M.Sc. degree have very less options compared to M.Tech and Engineering students. This is because, the industries expect students to develop software tools and innovative techniques rather than mere application of existing tools and techniques.

Then by force, the students from M.Sc. degree turn to academic sector for their placement. Most of them join as research fellows in various funded projects. They can't go for teaching at colleges or Universities without clearing National Eligibility Test (NET), an examination conducted by University Grants Commission (UGC) to become eligible for Lecturer ship in University/College. But the Geospatial Science subject is not there in the list of UGC NET and the students can't even apply for it.

Another problem is the students those who want to pursue their higher education/ Research have very less choices in getting their $\mathrm{PhD}$ in Geoinformatics. Since Geography, Geology, Environmental Science departments support their PhD research work in Geospatial Science, the students get their degree in any one of this subject. Imagine a student having a background in Botany in undergraduate level, Masters Degree in Geoinformatics and a Doctorate in Geography. He or She is ideal for teaching geospatial Science, but she/he cannot clear NET exam because of the above said problem.

\subsection{Role of Industries}

The Geospatial Industries pay a vital role in the growth and development of this science. North America and European countries take a lead because of collaborative work of both Industries and Universities. But in the Indian Scenario, there is a gap between geospatial industries and Universities.

They use the Indian students for low level of technological work and give meagre salary, whereas outsource the high level technical work. The Indian Industries are mostly franchise of American, European and Chinese Software companies. They look at the Indian geospatial community as potential users of their software rather the developers. It is because of our outdated curriculum and lack of advanced research infrastructure in the Indian Universities. 


\section{SUGGETIONSTO IMPROVE UNIVERSITY LEVEL GEOSPATIAL EDUCATION}

\subsection{Strengthening the teaching faculty and the curriculum}

The first and foremost thing is training the trainers i.e., strengthening the teaching fraternity. The Industries should come forward to train the teachers in the recent developments, so that knowledge can be transferred into the student community. For example LiDAR technology, Hyper spectral and Web GIS are still not in the syllabus of many universities. Object Oriented methodology, Automatic feature extraction methods are not taught to students because of non - availability of required software. Even though open source software freely available for teaching and learning, it is not the cup of tea for many faculties who don't have computer science background. It is difficult for them to customise the software according to their needs.

Hence the Industries should sponsor research programs and train the faculties, so that the industry will gain by getting trained student community (Figure 2) for further research and development. It is therefore a mutual benefit program.

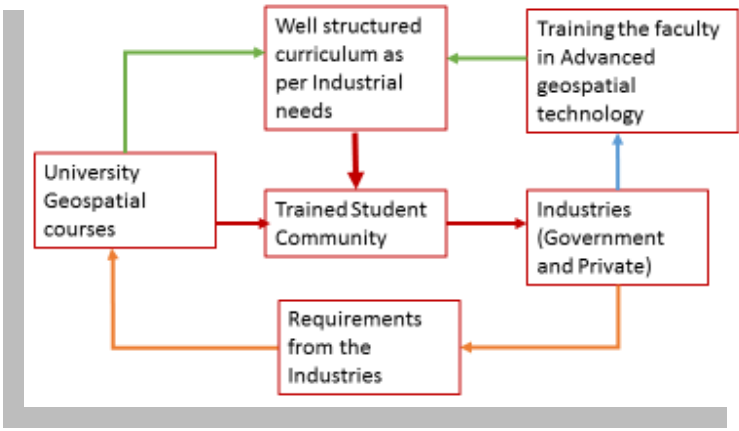

Figure 2 Expected relationship between Universities and Industries

The Government should encourage the growth and development of geospatial science by making changes in the data policy. For academic (teaching and Research) work, the required data should be supplied from authentic sources. The Government should sponsor the faculties to go for advanced training and motivate the Industries to take up this issues.

Variable course curriculum among the Universities offering Geo spatial courses, which needs to be based on some standard curriculum, with at least $60 \%$ of the course content similar. The Industries should fill the gap of demand and supply and assist in designing the curriculum by spelling out their demands. This way, the universities can supply the students with required capacity. Each university can specialise in any one field of geospatial science, so that the students will have their own speciality in the job market.

\subsection{Attractive Placement options}

Once again the role of Government and Industrial sector is imperative in the employment opportunities. The Government projects and various Government initiatives should consider the appointment of trained geospatial professionals. This will encourage the student community and will enhance the quality of Government projects.
The Industries should come forward for campus selection with attractive salary packages, so that brain migration will be stopped and the students' admissions in the Universities will increase.

The premier Institutions such as IIRS, NRSC, SAC (ISRO), Survey of India, NATMO and many more such institutions of national importance should come forward to appoint the students through National level Examinations and give opportunity to work in their Projects.

UGC/CSIR should consider the Geospatial Science as one of their subject for NET exam also will give as trained faculties to disseminate the geospatial education. This will really metamorphoses the quality and quantity of geospatial education in the universities.

\section{CONCLUSION}

Many Universities should start the Geospatial science courses at undergraduate level (B.Sc., B.Tech.). Students from science background in their +2 can be the ideal intake for these course. This UG courses will supply enough students with proper geospatial background for the Post Graduate level programs. This will actually give us better qualified students for high quality research at $\mathrm{PhD}$ level. Therefore strengthening the base is very much essential for quality education.

\section{REFERENCES}

Geospatial World., 2011. Vol 1(April) Issue 09

Geospatial World., 2014. Vol 05 (September) Issue 02

MHRD Report., 2013. Report of National task force on Geospatial Education. Minister of Human resource Development, Aug 2013.

Prithvish Nag ., 2010. Committee Report of DST, 2010

\section{Acknowledgements}

The author is thankful to Mr. Deepak Kumar for his inputs in writing this paper. Thanks to all students and faculties of School of Earth Sciences from central University of Karnataka for their support. 